\title{
ARCHAEOLOGICAL TESTIMONIES FROM THE ANCIENT PERIOD RELATED TO THE KNOWLEDGE AND USE OF HEALING SPRINGS IN EASTERN SERBIA
}

\begin{abstract}
The topic of this paper is ancient finds discovered in the vicinity of healing springs in the territory of present-day Serbia. The finds testify that the healing springs in this area were known, used and revered in the ancient period. Finds from sites in Milutinovac, Boljetin, Šarbanovac, Sumrakovac, Nikoličevo, Felix Romuliana and Sokobanja are presented.
\end{abstract}

KEYWORDS: HEALING SPRINGS, ANTIQUITY, SCULPTURES, GEM, SANCTUARIES, EASTERN SERBIA.

The aim of this paper is to establish whether healing springs were known and used during Antiquity in the area of today's Eastern Serbia. One of the best confirmations of this possibility is presented by the archaeological testimonies of the worship of the cult of Roman deities with iatric and/or soteriological characteristics (Asclepius, Hygieia, Hercules, Dionysus, Dioscuri, etc.), discovered in the close vicinity of the healing springs.

The importance of thermal and mineral springs in Antiquity is evidenced by the conclusion of S. Krunić, who, in her doctoral dissertation entitled "Roman Medical, Pharmaceutical and Cosmetic Instruments in the Upper Moesia Territory," made the following observation: "Healthy water, a communal network, public baths, space for gymnastic exercises, healing springs and thermal waters were the prerequisites for maintaining personal hygiene" (Крунић 2000: 3).

Extending the role of thermal and mineral waters from the practical to the sacral sphere, the same author also states that: "... it is no wonder that we most often find votive plates and sculptures in gratitude for healing and salvation right beside the ther- mal and healing springs" (Крунић 2000: 223).

It is reasonable to assume that a similar situation can also be expected near the healing springs in Eastern Serbia, which abound with extremely significant archaeological sites. This paper will cover the territories of the cities of Zaječar and Bor and the municipalities of Kladovo, Negotin, Knjaževac, Majdanpek, Boljevac and Sokobanja.

Archaeological evidence from Antiquity found close to healing springs regarding the worship of ancient deities with iatric and soteriological features was established in Milutinovac, Boljetin, Šarbanovac, Sumrakovac, Nikoličevo, Felix Romuliana and Sokobanja (Васиљевић 2014).

Information will be presented about the sites that can be associated with the topic of this work on the following pages.

Milutinovac is a settlement in the municipality of Kladovo in the Bor administration district. F. Kanitz recorded the existence there of a former healing water spring. The travel writer records evidence of a spring beneath the Čuka Mare hill (altitude 366 metres), northwest of Milutinovac, where there were remains of an earthen fortifi- 
cation from the First Serbian Uprising that was built on ancient foundations: "At the foot of this sharply profiled hill, there is a spring of rather tasty warm salt water, for which, not far from the village inhabited by Montenegrins three decades ago, exploratory drilling was performed 18 years ago in the hope that salt could be found, but without results" (Каниц 1989: 481-482).

Kanitz also noted that in the village of Milutinovac, there is a rectangular castle, approximately $50 \times 60$ metres in size, with some walls that are preserved up to a height of two metres. He goes on to say that he thought that traces of the castle would disappear in a very short time (Каниц 1989: 481-482).

P. Milošević and M. Jeremić conditionally identified the fortification, whose local name is not known, as Timena, as documented by Procopius. It was built at the point where the Danube is narrowest, to allow control of the large bank nearby, the existence of which further facilitated passage across the Danube. Since the site was threatened by the construction of the Đerdap II hydroelectric power plant, archaeological excavations were carried out (Milošević, Jeremić 1986: 245).

Research has shown that it was an early Byzantine fortification from the $6^{\text {th }}$ century, with approximate internal dimensions of 48-49.90 x $54 \mathrm{~m}$, and external dimensions of 51.80-53.30 x 57.80 $\mathrm{m}$. The corners of the fortifications are reinforced with one circular tower (the southern tower) and three ellipsoidal towers. In the middle of the coastal rampart, it was noted that there was a rectangular tower where the entrance to the fort was probably located. Portions of the staircase structures and exits to the walkway were discovered inside the ramparts. The thickness of the ramparts is 1.90 $1.95 \mathrm{~m}$. Finds such as fragments of early Byzantine amphorae and a semifollis of Justin II, dated in the seventh decade of the $6^{\text {th }}$ century, have been discovered (Milošević, Jeremić 1986: 246-249).

The selection of the location of the fortification in Milutinovac was certainly influenced by strategic reasons, primarily by the fact that it was built at the point where the Danubian Ključ is narrowest. However, it is believed that the existence of a nearby mineral spring had significance in the daily life of the fortification's inhabitants, so this site may be included in the list of sites associated with healing springs. The recorded existence of the former mineral spring in Milutinovac leads to conclusion that similar, today non-existent, springs could also have existed close to other sites within the area (Vasiljević 2018: 47-48).

Boljetin is a settlement in the Majdanpek Municipality. The existence of a healing spring there was also recorded by Felix Kanitz. However, the existence of springs is not recorded in contemporary literature. Kanitz noted that the ancient fortification, not far from the confluence of the Boljetin River and the Danube, is "on the opposite side of the hot spring that originates from the very river, not far from the bank" (Каниц 1985: 214).

The existence of a military camp, used from the $1^{\text {st }}$ to the $6^{\text {th }}$ century, was ascertained in the Boljetin area. It was built in the first half of the $1^{\text {st }}$ century, as an earthen fortification with palisades. During the second half of the $1^{\text {st }}$ century, masonry ramparts were constructed. The fortification was abandoned in the $2^{\text {nd }}$ century, perhaps during Hadrian's reign. It was restored for the first time, just before Aurelian's withdrawal from Dacia. It was devastated in a fire during the first decades of the $5^{\text {th }}$ century and was rebuilt for the second time during the great Justinian restoration in the $6^{\text {th }}$ century (Зотовић $1982 / 1983: 211$ ).

The dimensions and interior decoration of the earthen castle are unknown. The conclusion about its existence is made on the basis of stratigraphy and analysis of architectural remains from the $1^{\text {st }}$ century. Remains of fortifications from the second half of the $1^{\text {st }}$ century were only found in the southeastern half of the camp (Fig. 1). The dimensions of the oldest masonry fortification have not been precisely determined. It is known that the northeast - southwest axis corresponded to the length of the axis of the reconstructed fortification, while the northwest - southeast axis was slightly longer 


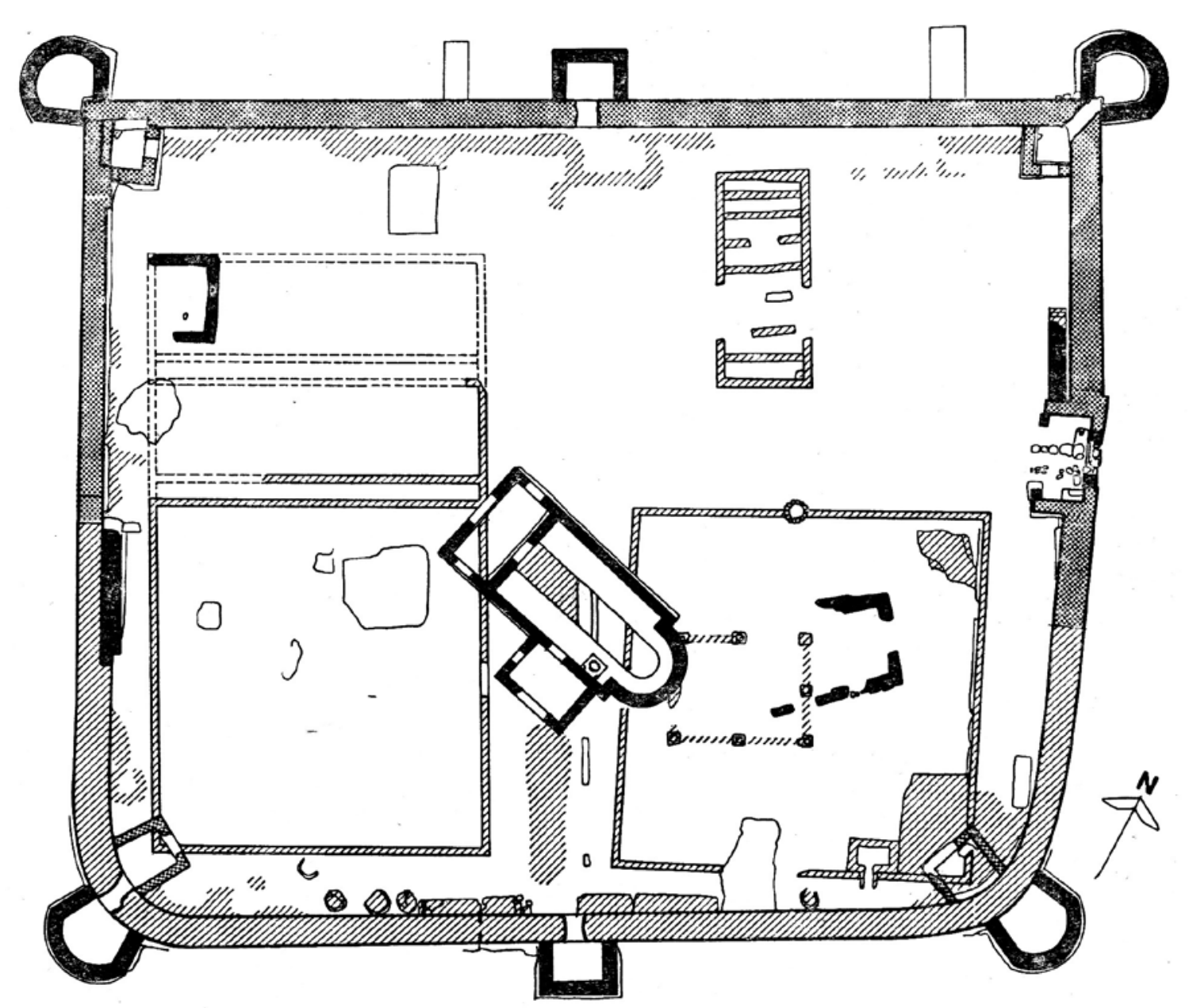

Fig.1 Plan of the fortification in Boljetin (according to: Зотовић Љ. 1982/1983: 213, сл. 2).

than the fortification axis of the subsequent construction phase. During this phase, the fortification inhabitants consisted of members of the Legion IV Flavia. The fortification was demolished from the north-western side, from the direction of the Boljetin River, at the part near its confluence into the Danube. (Зотовић 1983: 214-215).

Several structures from this period have been preserved inside the fortification. Of particular interest is building I, made of polygonally cut stone blocks, secured with mortar. It is clear that these are remains of a Roman bath over which a Christian religious building was constructed, bearing in mind its shape, but perhaps also there is a suggestion that it was associated with a cult related to the use of hot water from a nearby thermal spring (Зотовић 1983: 215-216).
During the first renewal of the fortification, just before Aurelian's withdrawal from Dacia, the three preserved ramparts were rebuilt, and a north-western rampart and the northern half of the north-eastern rampart were built from the base. The inner towers of the fortification were also built on this occasion. The interior of the fortification was filled in this phase with tents, arranged in an almost regular series of northeast-southwest directions. It is assumed that during this period the camp's inhabitants consisted of part of the Legion VII Claudia. It is considered that the camp was abandoned in the first decades of the $5^{\text {th }}$ century. The time when the camp was abandoned is marked by a layer of demolition, while traces of fire are only visible in the eastern part (Зотовић 1983: 220-222).

During the early Byzantine restoration of the 
limes, the fortification at Boljetin was also renewed. It is believed that on this occasion only relatively well-preserved ramparts from the older phases were extended and partially renewed, and that adaptations on the gates were made as well, while the outer towers were built from the foundations. As already mentioned above, in the central part of the fortification, above the Roman bath, a church was built. All parts of the church were built using alternating masonry of cut and broken stone and brick. The church, in its restored or only levelled, devastated condition, was a cult site related to a medieval necropolis. It is possible that the remains of the church were not visible during this period, but it only remained in the minds of the inhabitants as a cult place where burials were performed (Зотовић 1983: 223-224).

According to numismatic finds, it is concluded that cessation of life in the fortification occurred during the last years of the $6^{\text {th }}$ century, when the camp was devastated by a large fire (Зотовић 1983: 225). V. Kondić identified the fortification in Boljetin as Smorna, recorded by Procopius (Кондић 1971: 54-58).

During the exploration of the medieval necropolis formed within the ramparts of the ancient fortification, the existence of 97 skeletal graves was recorded. It was found that one grave, marked as number 72 , originates from the Roman period. It is a child's grave, oriented southeast-northwest, with the head facing northwest. It was discovered beneath an intact daub construction. There were no grave goods. The other graves belong to a medieval necropolis dated from the $12^{\text {th }}-14^{\text {th }}$ centuries (Ерцеговић-Павловић 1983: 227-230).

During the exploration of the necropolis, within the Early Byzantine layer, a hoard was discovered, consisting of eleven crescent shaped copper and bronze earrings decorated with a filigree technique, which S. Ercegović Pavlović attributes to the Slavic population and dates to the $10^{\text {th }}-11^{\text {th }}$ century (Eadem 1969: 83-95).

Previously, we described being convinced of the longevity and continuity of life in Boljetin, that is, the ancient and Byzantine Smorna. An answer has yet to be found to the question of the importance of the thermal spring, recorded by Kanitz, for the functioning of the fortification. It is probable that the strategic importance of the location was a primary factor in selecting the site for building the castrum. Nevertheless, it is supposed that for the daily life of soldiers and all others residing in the castrum or its immediate vicinity, an easily accessible thermal spring was of great importance. The existence of a Roman bath almost at the centre of the fortification, with a relatively small area with hypocaust heating, indicates the possibility that thermal water from the spring was used in the bath. It is easy to assume that in this case, a certain cultic worship for thermal waters had developed, creating such a relationship also to the place where the waters were used, that is, the balneum. The significance of the cult site extended through the early Byzantine basilica and medieval necropolis (Vasiljević 2018: 48-51).

The Sarbanovac settlement is located in the territory of the municipality of Bor. Some of the ancient sites in Šarbanovac can be associated with the presence of healing waters. From the Early Iron Age there are random metal finds from a hoard or a grave. One of the hot springs in Šarbanovac might have represented, in ancient times, a cult place where votive offerings were placed and access to this area was protected by two ancient fortifications (Gradiška čuka and Zdravi kamen). Two settlements from the Middle Ages (the $10^{\text {th }}-11^{\text {th }}$ and the $15^{\text {th }}$ century) have been recorded there.

The frequently cited F. Kanitz states that Roman arrows, tools and coins were found near the Šarbanovac hot spring (Kanitz 1989: 406). A. Jovanović considers that it is possible that the cult goods by the thermal springs marked sacred centres of an iatric character. Findings of coins are common in such contexts, while arrows can represent a kind of monetary equivalent. The finding of tools in a cult setting is peculiar, however. It may be possible to draw parallels with the mining ingots laid at the foundations of buildings as a 
prophylactic element. The same author comments that the place of worship of a local cult of iatric character associated with thermal springs is probably an interpretatio romana of the cult of Apollo or Artemis (Јовановић 2004: 193).

S. Jovanović recorded the remains of two ancient fortifications near Šarbanovac, in the Jelašnica River gorge. One is on the Gradiška čuka hill (907 metres above sea level) recorded by Kanitz. There was probably an ore processing centre within the fortification. Another fortification was found on Zdravi kamen (altitude of about 600 metres). The fortification at Zdravi kamen was built on a plateau accessible only from the south-western side. The preserved parts of the ramparts are generally recognised by the terrain configuration. The ancient fortifications near Šarbanovac can be associated with the provision of ancient mines and communications for the transportation of ores to the Timacum Minus mining station (Јовановић 1986: 195-197; Gacović 2010: 47).

It can be assumed that the inhabitants of the aforementioned fortifications knew, used, and probably attached cult significance to the nearby healing springs. Perhaps in this way, the emergence of arrows as cult offerings can be explained.

At this point it can be concluded that the spring in Šarbanovac represented a place where iatric cults were worshiped, to which votive gifts were offered. Unfortunately, no remains of Roman immovable objects or objects of the cult have been discovered, on the basis of which could be determined the mode of healing water use and the specific cults worshipped at this place.

Sumrakovac is a settlement in the territory of the Boljevac municipality. In this area, from the ancient period, a villa rustica and a random find of a gem with a representation of Dioscuri were registered (Fig. 2). At the Selište site, in an area of approximately one square kilometre, there are remains of Roman structures, including bricks measuring 40 x $40 \mathrm{~cm}$ (Гарашанин, М., Гарашанин Д. 1951: 133).

This is probably the same site where A. Jo-

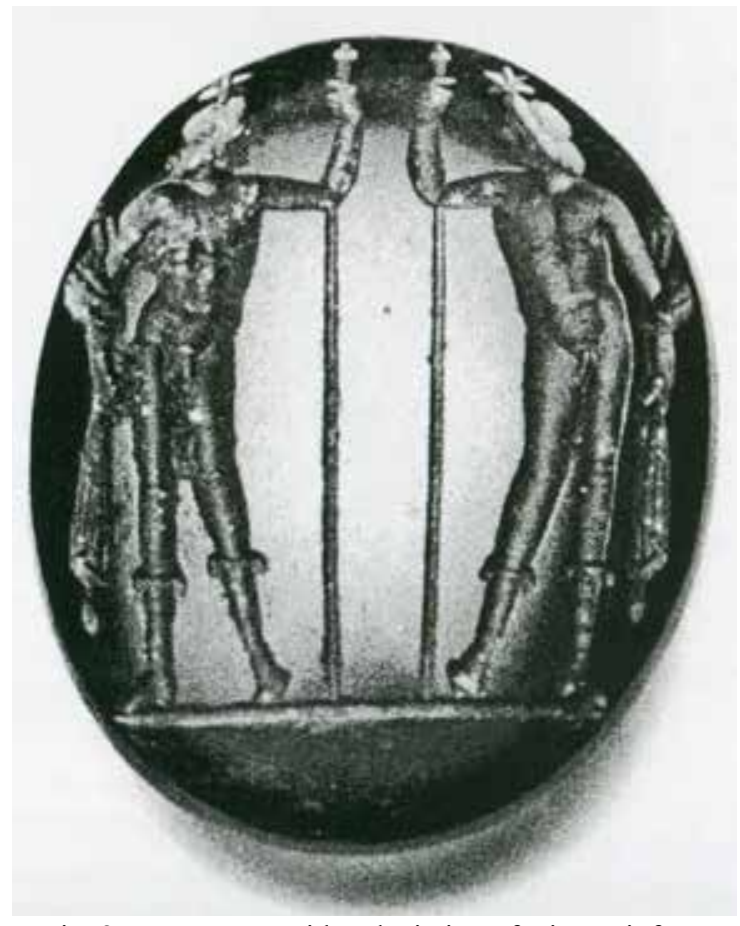

Fig. 2 Roman gem with a depiction of Dioscuri, from Sumrakovac, 3rd century (according to: Јовановић A. 2004: 205, сл. 114).

vanović recorded the remains of an ancient villa rustica. The villa in Sumrakovac was built on a convenient extension above the river, similar to other buildings of this type in the surrounding area (Јовановић 2004: 183, 187; Gacović 2010: 61).

An accidental find of a gem with a representation of Dioscuri in a standing position leaning on a sceptre originates from Sumrakovac. The composition has a very interesting concept: the heraldic axis is accentuated by the sceptres, and the curved figures follow the oval edge of the object. A. Jovanović believes the reason for such a presentation could be the deification of Antinous or the introduction of the young Caesars, Caracalla and Geta, into the imperial programme of Emperor Septimius Severus. The author finds confirmation for the second assumption in the arrangement with a section on the base, which is why the gem resembles coins of the $3^{\text {rd }}$ century, and it is dated accordingly. (Јовановић 2004: 213).

It is believed that the aforementioned location of the find near the spring in Sumrakovac was certainly not accidental. The Dioscuri cult had 


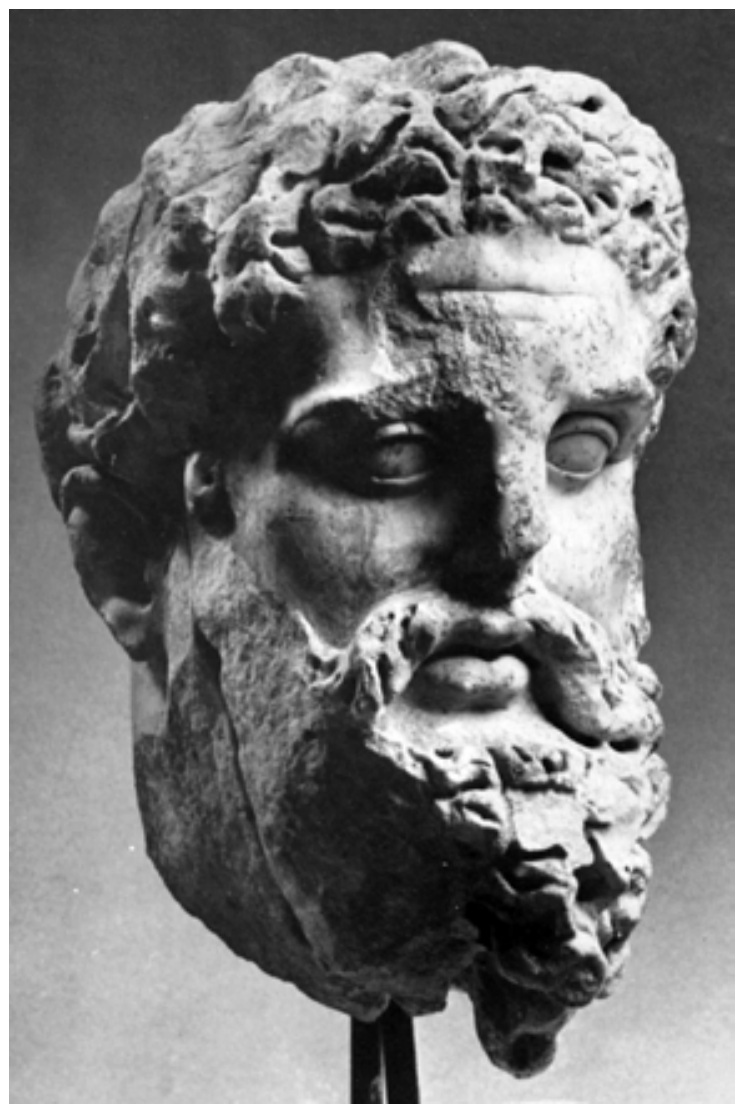

Fig. 3 Head of Hercules from Felix Romuliana (according to: Живић 2003: 36, сл. 18).

significant iatric and soteriological elements and could have been worshipped in the environment of healing springs.

The remains of a small single naved church dated to the $14^{\text {th }}-15^{\text {th }}$ century are in the vicinity of Sumrakovac (Јанковић, Вуксан 2004: 271). Unfortunately, the denomination of the church is not known.

The indications are sufficient to conclude that the waters in Sumrakovac were used in the ancient period and that their healing properties were known, as evidenced by the find of the gem with the representation of Dioscuri. To date, the remains of a Roman bath within the aforementioned villa rustica have not been confirmed, but it is believed that the existence of a thermae can be assumed.

Nikoličevo is a settlement in the municipality of Zaječar. In the area of Nikoličevo no archaeological sites have been registered, but the find of an unfinished statue of Heracles in Rgotina has led A. Jovanovic to the notion that the deity could have been worshiped as the patron saint of thermal springs in the nearby Nikoličevo (Јовановић 2004: 193), (Fig.3).

The aforementioned assumption remains in the theoretical domain, but it is believed that it sufficiently points to the possibility of use, as well as the cultic reverence of the spring in Nikoličevo in Antiquity.

Gamzigradska Banja is located 11 kilometres west of Zaječar. One of the oldest hydroelectric power plants in Serbia is in Gamzigradska Banja.

The Crna reka valley, where the Gamzigrad site and the Imperial Palace of Felix Romuliana are located, is surrounded by mountains of volcanic origin and offers all the conveniences for life. Among the many natural benefits there, the thermal springs also stand out, through which the locals of these area, as M. Lazić wrote, "gained vitality and encouraged their pagan religiosity" (Лазић 2010: 21).

The first evidence of prehistoric cultures in the area of Gamzigrad were discovered during the 1970s, during the exploration of the Roman imperial palace. Several prehistoric sites have been explored in the vicinity of Gamzigrad: the Eneolithic site (Bubanj - Sălcuţa - Krivodol) on Beligovo hill, near Gamzigradska Banja; the Bronze Age necropolis on Magura hill (Gamzigrad culture); a multi-layered prehistoric site on Banjska stena, near Gamzigradska Banja (Bubanj- Sălcuţa -Krivodol, Coţofeni - Kostolac Culture); a Bronze Age settlement in a rock shelter near Gamzigradska Banja; a Bronze Age and Early Iron Age settlement on the route to Miletov bunar, near a Roman quarry; and a Bronze Age settlement in the village of Zvezdan (Gamzigrad culture). More than thirty sites from various prehistoric epochs were registered by field surveys in the vicinity of the imperial palace.

Archaeological research at Gamzigrad confirmed the existence of a Roman settlement before the construction of the monumental Felix Romuliana, the palace of the Emperor Galerius. 
In older literature, the Roman remains from the period before the palace was build had been interpreted as an ancient villa rustica (Петковић 2010: 33; Srejović, Vasić 1994: 56-57).

Felix Romuliana is a topic that numerous researchers have been occupied with. At this point, only finds and immovable objects which can be associated with the use of nearby healing springs will be taken into consideration.

The creation of a bibliography of works dedicated to the site of the Imperial Palace, Felix Romuliana, the later Slavic Gamzigrad, would be a great challenge for any researcher. One of the most important sites that the Roman Empire left to humanity as part of its legacy has been investigated from many aspects, but the possibility of its connection to nearby healing springs in today's Gamzigradska Banja remains difficult to establish.

Regarding the immovable finds, the most significant for this paper is the building with remains of a hypocaust heating system. It is located below the entrance to the south tower of the western gate of the younger fortification. This is a late antique thermae built on the most south-eastern part of the palace, at the lowest elevation of the terrain. Two construction phases and alterations were observed. The bath covers an area of approximately 28.5 metres (north-south direction) and 14.6 metres (east-west direction), that is $403.56 \mathrm{~m}^{2}$. Originally, there were two niches in the western wall of the thermae hall, plastered and painted, provided perhaps for sculptures of Asclepius and Hygieia (Fig. 4). There is a possibility that a white marble Asclepius statue, discovered in the north-western part of the site was originally located in this place (Чанак-Медић, Стојковић-Павелка 2010: 100).

Several finds were discovered within the palace that testify to the worship of deities with iatric-soteriological functions. Attention should be drawn to parts of the Hercules statue (though, in the general context, it may rather be associated with the imperial cult) and the torso of Asclepius (the existence of the statue of Hygieia in the same spatial and cult context was also assumed), while M. Živić believes

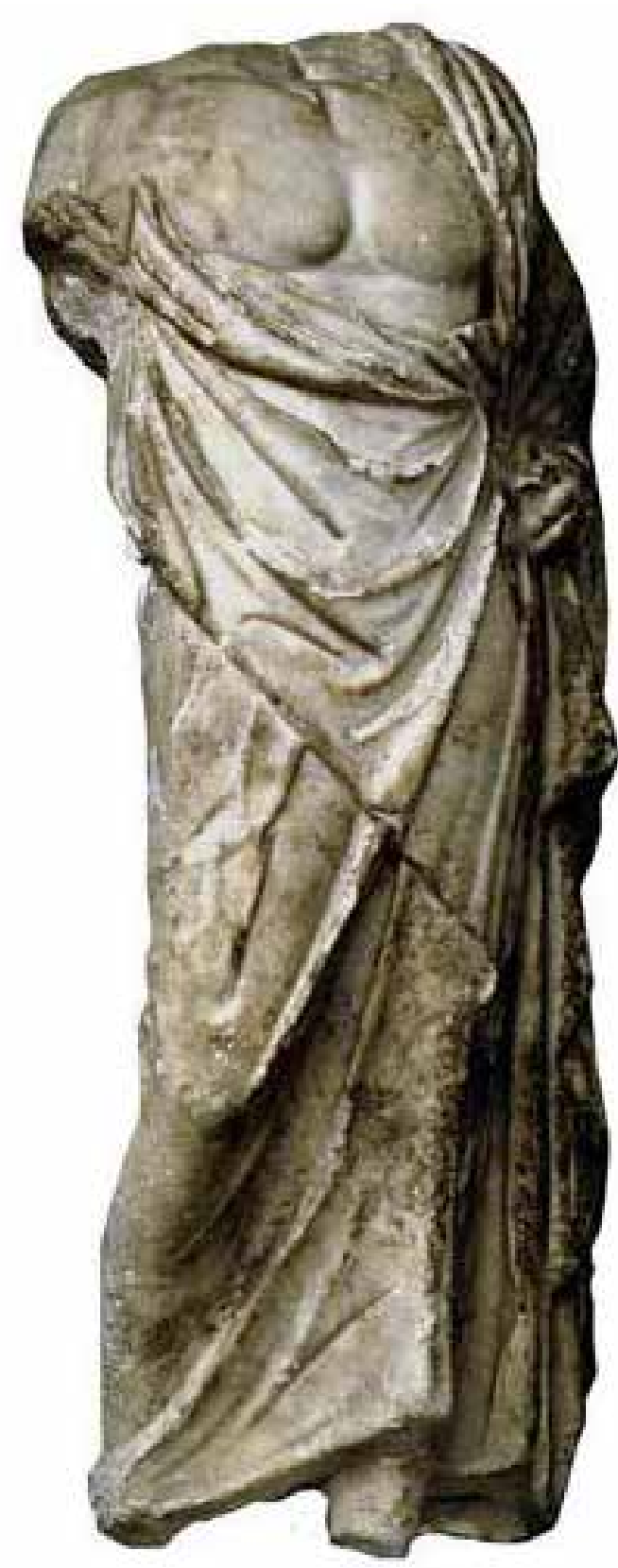

Fig. 4 Statuette of Asclepius from Felix Romuliana (according to: Живић 2003: 79).

that there are sufficient indications confirming the worship of the Apollo cult. Also added to this list will be a famous mosaic with a presentation of Dionysus (Живић 2010: 107-134).

It should be emphasised that all stated finds can be considered as expected in the complex of the great imperial palace, but without the missing elements (inscriptions or direct allusions), they 
cannot be used as definitive proof of the knowledge and worship of the nearby healing springs. However, regarding the discovery of direct confirmation of the use of springs from Gamzigrads$\mathrm{ka}$ Banja at the time of the existence of the ancient site, the aforementioned finds could also be viewed in this context.

The undisputed fact is that Emperor Galerius built a palace and a mausoleum near the place of his birth. As a well-grounded assumption, the possibility can be stated that the choice of the precise location of the imperial complex was influenced by the presence of nearby healing springs, as a place filled with mysticism and numerous beliefs. The long-term belief in the miraculous properties of healing springs in Gamzigradska Banja is testified to by the Wallachian song for the farewell of the deceased, cited by A Jovanović, as an example of the belief that the deceased should be washed in fairy water (in this case, certainly, healing water) in order that the body, with a certain mummification process, stay preserved until Apollo's return from the land of Hyperborean (Јовановић 2012: 159-160).

The conclusion is that it is very likely that healing springs in today's Gamzigradska Banja were known and used by the inhabitants of ancient Romuliana, who may have left material traces regarding the significance and meaning of the springs in their time, which may be discovered in the future.

Sokobanja is a town and spa in the municipality of the same name. It is located at an altitude of 400 metres. The Moravica River runs through Sokobanja.

Literature records the information that a find of coinage of Justin II originates from the Gradište site in Čitluk and Trubarevac, near Sokobanja (Рашковић 2010: 177). A Maurice solidus (582-602), minted in Constantinople, was found at the Gradište site in Ozren, near Sokobanja (Рашковић и Гаврић 2011: 463).

Near the bath in Sokobanja, F. Kanitz recorded the existence of ancient finds and walls, as well as a Roman vaulted canal. The travel writer states that he observed the existence of a drainage canal with a semi-circular vault of thick, burnt bricks, dating it to an ancient period. Based on these observations, it is concluded that springs in Sokobanja were used as early as the ancient period. The same author believed that the medieval Soko Grad, as well as the adjacent city of Tatomir, were built on ancient grounds. (Каниц 1989: 114-115).

The existence of an ancient fresco-decorated building is possible at the Glogan site, $2.5 \mathrm{ki}$ lometres southeast of Sokobanja, or about 400 metres east of Soko Grad. The structure has not been archaeologically researched, so no definitive conclusions can be drawn about it (Милојевић, Милошевић, Кајтез 2013: 47-52).

The Trebič site is located five kilometres west of Sokobanja, on a shallow slope between the homonymous stream and the Sokobanja - Aleksinac road. It covers an area of $200 \times 100$ metres. It was not mentioned in the literature until 1968, although finds from the ancient and early Byzantine period (statue of Mercury, fibulae, pottery, building material), were known, including coins from the $1^{\text {st }}-6^{\text {th }}$ centuries, today in a private collection (Petrović 1968: 132-133, 135).

The motive for archaeological excavations was the activity of amateur archaeologists and the discovery of two gold rings, two massive bronze buttons filled with lead, and a brick with the inscription MAXIMUS, when a walled tomb was excavated. The tomb, built of bricks and dug into the subsoil, is oriented north - south. The external dimensions are $2.46 \times 1.70 \mathrm{~m}$. It was paved with square-shaped bricks. The aforementioned brick with an inscription was found in the floor of the tomb. The larger number of discovered roof tiles (tegulae) suggests that the tomb was covered with a double-pitch roof. The remains of carbonised bones were found in the excavated earth, so it was probably an incineration tomb. Above the row of bricks on the north side is a pebble and broken stone wall joined with lime mortar, which, together with identical walls discovered nearby, is part of 
a building functionally and chronologically separated from the tomb (Petrović 1968: 133-134).

Two bronze buttons identical to those found earlier, a small ring made of bent bronze wire with endings in the form of stylised snake heads, bronze cosmetic tweezers, and the upper part of a bone overlay ornamented with incisions were found in the earth that was illegally dug from the grave. According to the construction and finds, the tomb is dated to the $2^{\text {nd }}-3^{\text {rd }}$ centuries. The assumption about the existence of a Roman necropolis has not been confirmed, so it was probably a roadside tomb. The building above the tomb, based on analogies in the method of construction and earlier finds of coins from the $6^{\text {th }}$ century, is determined to be from the early Byzantine period. It should be mentioned that the find of a flint knife and several pottery fragments testifies to the existence of a prehistoric settlement (Petrović 1968: 134-135). Although there is no archaeological evidence to support Kanitz's assumptions regarding the use of local thermal waters in the Roman period, it is believed that the theory is not ungrounded and that the travel writer noted traces of the use of springs in ancient times. In accordance with this assumption, it is reasonable to consider the possibility that the medieval Soko Grad was built on the remains of an ancient fortification that protected thermal springs.

An overview of the sites and finds indicates that, during the ancient period, the healing springs were known, used and worshipped in the area which is the topic of this paper. Future research will certainly expand the list of sites known to the population in Antiquity, and also provide interpretations that will broaden the knowledge of the situation in places where ritual worship and gratitude for the healing properties of mineral spring water have already been established.

\section{$* * *$}

Arheologija i prirodne nauke (Archaeology and Science) is an Open Access Journal. All articles can be downloaded free of charge and used in accordance with the licence Creative Commons
- Attribution-NonCommercial-NoDerivs 3.0 Serbia (https://creativecommons.org/licenses/bync-nd/3.0/rs/.

Časopis Arheologija i prirodne nauke je dostupan u režimu otvorenog pristupa. Članci objavljeni u časopisu mogu se besplatno preuzeti sa sajta i koristiti u skladu sa licencom Creative Commons - Autorstvo-Nekomercijalno-Bez prerada 3.0 Srbija (https://creativecommons.org/licenses/by$\mathrm{nc}-\mathrm{nd} / 3.0 / \mathrm{rs} /$.

\section{BIBLIOGRAPHY}

\section{Ерцеговић Павловић, С. 1969}

Остава наушница са римско-византијског кастела из Бољетина на Дунаву, Старинар (н. c.) XX: 83-95.

(Ercegović Pavlović, S. 1969

Ostava naušnica sa rimsko-vizantijskog kastela iz Boljetina na Dunavu, Starinar (n. s.) XX: 83-95.)

\section{Ерцеговић Павловић, С. 1982/1983}

Бољетин, средњовековно насеље и некропола, Старинар (н.с.) XXXIII-XXXIV: 225-229.

(Ercegović Pavlović, S. 1982/1983

Boljetin, srednjovekovno naselje i nekropola, Starinar (n.s.) XXXIII-XXXIV: 225-229.)

\section{Чанак Медић, М. и Стојковић Павелка, Б. 2010}

Архитектура и просторна структура царске палате, у: Felix Romuliana Гамзиград, Славиша Перић (ур.), Београд: Археолошки институт: 33-42.

(Čanak Medić, M. i Stojković Pavelka, B. 2010

Arhitektura i prostorna struktura carske palate, u: Felix Romuliana Gamzigrad, Slaviša Perić (ur.), Beograd: Arheološki institut: 33-42.)

\section{Gacović, S. 2010}

Antičko rudarstvo na tlu istočne Srbije, Zbornik radova Muzeja rudarstva $i$ metalurgije (Bor) 10/12: 41-78. 
Гарашанин, М. и Гарашанин, Д. 1951

Археолошка налазишта у Србији, Београд: Просвета.

(Garašanin, M. i Garašanin, D. 195

Arheološka nalazišta u Srbiji, Beograd: Prosveta.)

\section{Јанковић, Ђ. и Вуксан, М. 2004}

Област Бора у средњем веку, у: Бор и околина у праисторији, антици и средњем веку, ур. Мирослав Лазић, Бор: Музеј рударства и металургије у Бору - Београд: Центар за археолошка истраживања Филозофског факултета у Београду: 231-280.

(Janković, Đ. i Vuksan, M. 2004

Oblast Bora u srednjem veku, u: Bor i okolina u praistoriji, antici i srednjem veku, ur. Miroslav Lazić, Bor: Muzej rudarstva i metalurgije u Boru - Beograd: Centar za arheološka istraživanja Filozofskog fakulteta u Beogradu: 231-280.)

\section{Јовановић, А. 2004}

Бор и околина у античком периоду, у: Бор $и$ околина у праисторији, антици и средњем веку, ур. Мирослав Лазић, Бор: Музеј рударства и металургије у Бору - Београд: Центар за археолошка истраживања Филозофског факултета у Београду: 165-229.

(Jovanović, A. 2004

Bor i okolina u antičkom periodu, u: Bor i okolina u praistoriji, antici i srednjem veku, ur. Miroslav Lazić, Bor: Muzej rudarstva i metalurgije u Boru - Beograd: Centar za arheološka istraživanja Filozofskog fakulteta u Beogradu: 165-229.)

\section{Јовановић, А. 2012}

Белешке о култу воде у римским провинцијама на тлу Србије, Зборник Матище српске за класичне студије 14: 151-162.

(Jovanović, A. 2012

Beleške o kultu vode u rimskim provincijama na tlu Srbije, Zbornik Matice srpske za klasične studije 14: 151-162.)

\section{Јовановић, С. 1986}

О античком рударењу на старој планини, Гласник Српског археолошког друштва 3: 195200.

(Jovanović, S. 1986

O antičkom rudarenju na staroj planini, Glasnik Srpskog arheološkog društva 3: 195-200.)

\section{Каниц, Ф. 1985}

Србија земла и становништво - од римског доба до краја XIX века, I књига, Београд: Српска књижевна задруга и ИРО Рад.

(Kanic, F. 1985

Srbija zemlja i stanovništvo - od rimskog doba do kraja XIX veka, I knjiga, Beograd: Srpska književna zadruga i IRO Rad.)

\section{Каниц, Ф. 1989}

Србија земла и становништво - од римског доба до краја XIX века, II књига, Београд: Српска књижевна задруга - ИРО Рад.

(Srbija zemlja i stanovništvo - od rimskog doba do kraja XIX veka, II knjiga, Beograd: Srpska književna zadruga - IRO Rad.)

\section{Кондић, В. 1971}

Cantabaza, Smorna, Campsa, Старинар (н. с.) XXXII: 53-58.

(Kondić, V. 1971

Cantabaza, Smorna, Campsa, Starinar (n. s.) XXXII: 53-58.)

\section{Крунић, С. 2000}

Римски медицински, фармацеутски и козметички инструменти на територији Горње Мезије, Докторска дисертација, Филозофски факултет, Универитет у Београду.

(Krunić, S. 2000

Rimski medicinski, farmaceutski $i$ kozme-tički instrumenti na teritoriji Gornje Mezije, Doktorska disertacija, Filozofski fakultet, Univeritet $u$ Beogradu.) 


\section{Лазић, М. 2010}

Праисторијска насеља и некрополе у Гамзиграду и његовој околини, у: Felix Romuliana Гамзиград, Славиша Перић (ур.), Београд: Археолошки институт: 21-28.

(Lazić, M. 2010

Praistorijska naselja i nekropole u Gamzi-gradu i njegovoj okolini, u: Felix Romuliana Gamzigrad, Slaviša Perić (ur.), Beograd: Arheološki institut: 21-28.)

\section{Milošević, P. i Jeremić, M. 1986}

Le castellum à Milutinovac, Бердапске свеске III: 245-263.

(Milošević, P. i Jeremić, M. 1986

Le castellum à Milutinovac, Đerdapske sveske III: 245-263.)

\section{Милојевић, П., Милошевић С. и Кајтез, И} 2013

Грађевина са остацима фреско сликарства у Сокобањи, Караџић - часопис за историју, етнологију, археологију и уметност, нова серија (Алексинац) 5: 47-56.

(Milojević, P., Milošević S. i Kajtez, I. 2013

Građevina sa ostacima fresko slikarstva $\mathrm{u}$ Sokobanji, Karadžić - časopis za istoriju, etnologiju, arheologiju i umetnost, nova serija (Aleksinac) 5: 47-56.)

\section{Петковић, С. 2010}

Римски Гамзиград пре царске палате, у: Felix Romuliana Гамзиград, Славиша Перић (ур.), Београд: Археолошки институт, 33-42.

(Petković, S. 2010

Rimski Gamzigrad pre carske palate, u: Felix Romuliana Gamzigrad, Slaviša Perić (ur.), Beograd: Arheološki institut, 33-42.)

\section{Petrović, P. 1968}

Trebič kod Sokobanje, Arheološki pregled 10: 132-135.

\section{Рашковић, Д. 2010}

Примери налаза новца на локалитетима рановизантијских утврђења на југу централне Србије, Ниш и Византија IX: 171-185.

(Rašković, D. 2010

Primeri nalaza novca na lokalitetima ranovizantijskih utvrđenja na jugu centralne Srbije, Niš $i$ Vizantija IX: 171-185.)

\section{Рашковић, Д. и Гаврић, Г. 2011}

Налази новца са рановизантијских утврђења у крушевачком крају, Зборник Народног музеја, Београд XX-1: 443-470.

(Rašković, D. i Gavrić, G. 2011

Nalazi novca sa ranovizantijskih utvrđenja $\mathrm{u}$ kruševačkom kraju, Zbornik Narodnog muzeja, Beograd XX -1: 443-470.)

\section{Srejović, D. and Vasić, Č. 1994}

Imperial Mausolea and Consecration memorials in Felix Romuliana (Gamzigrad, Eastern Serbia), Belgrade: Faculty of Philosophy.

\section{Васиљевић, Љ. 2014}

Експлоатащија и значај термалних извора у римском периоду на територији Србије, Докторска дисертација, Филозофски факултет, Универзитет у Београду.

(Vasiljević, Lj. 2014

Eksploatacija i značaj termalnih izvora u rimskom periodu na teritoriji Srbije,

Doktorska disertacija, Filozofski fakultet, Univerzitet u Beogradu.)

\section{Vasiljević, Lj. 2018}

Archaeological sites from antiquity registered in the surroundings of hot springs along the Danube limes in Serbia, Archaeology and Science 13 (2017): 47-70.

\section{Зотовић, Љ. 1982/1983}

Бољетин (Smorna), римски и рановизантијски логор, Старинар (н.с.) XXXIII-XXXIV: 212-225. 
(Zotović, LJ. 1982/1983

Boljetin (Smorna), rimski i ranovizantij-ski logor, Starinar (n.s.) XXXIII-XXXIV: 212-225.)

Живић, М. 2010

Уметничка остварења у царској палати, у: $F e$ lix Romuliana Гамзиград, Славиша Перић (ур.), Београд: Археолошки институт, 107-140.

(Živić, M. 2010

Umetnička ostvarenja u carskoj palati, u: Felix Romuliana Gamzigrad, Slaviša Perić (ur.), Beograd: Arheološki institut, 107-140.)

REZIME

ARHEOLOŠKA SVEDOČANSTVA IZ ANTIČKOG PERIODA VEZANA ZA POZNAVANJE I KORIŠĆENJE LEKOVITIH IZVORA U ISTOČNOJ SRBIJI

KLJUČNE REČI: LEKOVITI IZVORI, ANTIKA, SKULPUTRE, GEMA, SVETILIŠTA, ISTOČNA SRBIJA.

Lekoviti izvori oduvek su privlačili pažnju stanovništva, koje je koristilo njihove blagodeti, a često se dešavalo i da svoje naseobine podignu u njihovom neposrednom okruženju. To sigurno nije bio izuzetak ni kod stanovništva koje je, u antičkom periodu, naseljavalo prostore današnje Istočne Srbije, što nagoveštavaju i brojni arheološki nalazi otkriveni u navedenom kontekstu.
Putopisac F. Kanic zabeležio je da su se, u blizini utvrđenja u Milutinovcu i Boljetinu, nalazili izvori lekovite vode. Isti autor beleži da se, kod toplog izvora u Šarbanovcu, nalaze rimske strelice, oružje i novac, koji se mogu smatrati za kultne priloge. Savremeni autori pretpostavljaju da se u Šarbanovcu nalazilo mesto poštovanja lokalnog kulta ijatričkog karaktera, verovatno interpretatio romana kulta Apolona ili Dijane. Kanic je smatrao i da su Rimljani poznavali i koristili izvore u Soko Banji, o čemu svedoče brojni antički lokaliteti u okruženju.

U blizini vile rustike u Sumrakovcu otkrivena je gema sa predstavom Dioskura, što ukazuje na mogućnost poštovanja božanstava vezanih za obližnje lekovite izvore. Nalaz nedovršene statue Herkula nagoveštava da bi on mogao biti zaštitnik izvorišta u Nikoličevu. Priča se zaokružuje osvrtom na carku palatu, Feliks Romulijanu, podignutu nadomak izvora u Gamzigradskoj Banji.

Pregled lokaliteta registrovanih u blizini lekovitih izvora na teritoriji današnje Istočne Srbije, pokazao je postojanje velikog spektra nalazišta koja se, direktno ili posredno, mogu povezati sa eksploatacijom njihovih voda.

Stanje istraženosti većine lokaliteta nije dovoljno da bi se stekle precizne slike o nekadašnjim banjskim kompleksima i kultnim mestima pored lekovitih izvora, ali određene indicije više nego jasno ukazuju da su blagodeti pojedinih vrela bile poznate, korišćene i poštovane tokom antičke epohe. 